\title{
PRESCHOOL:
}

Jurnal Pendidikan Islam Anak Usia Dini

Volume 1, Nomor 1, Juli-Desember 2020 Hal. 08-13

\section{ANAK DALAM PATOLOGI KEHIDUPAN SEKSUAL KELUARGA TRANSMIGRAN}

\author{
Nur Rahmah ${ }^{1}$, Subhan $^{2}$, Esti Ningsih ${ }^{3}$, Yusannang ${ }^{4}$ \\ ${ }^{1234}$ PIAUD IAIN Palopo J1. Agatis Balandai Kota Palopo Sulawesi Selatan \\ email: ${ }^{1}$ nur_rahmah@iainpalopo.ac.id, ${ }^{2}$ subhan@iainpalopo.ac.id, ${ }^{3}$ esti@gmail.com, ${ }^{4}$ yusannang@gmail.com
}

\begin{abstract}
Transmigrant families must deal with the territorial transitional problems of new territories. In new areas, families are not easy to start fulfilling epective food because of the unprepared land conditions. Many families lack the material to build a "decent" living house, which causes them (transmigrant families) to only live in a single bear garden house (hut). This situation has a psychological effect on the child, especially sexual behavior that is imitated by the sexual condition of the family (mother and father) which is often carried out in the same room (bedroom) as the child. This study seeks to clarify the impact of this context which is seen from three things namely sexual imitation behavior, influential factors and the role of teachers and parents in sexual selfrevitalization of children.
\end{abstract}

Keywords: child, sexual, transmigrant family

\begin{abstract}
ABSTRAK
Para keluarga transmigran harus menghadapi masalah transisional wilayah baru secara teritorial. Di daerah yang baru, para keluarga tidak mudah memulai pemenuhan pangan epektif karena kondisi lahan yang belum siap. Banyak keluarga yang kekurangan bahan untuk mendirikan rumah "layak" tinggal yang menyebabkan mereka (para keluarga transmigran) hanya tinggal di rumah kebun (gubuk) beruang tunggal. Kndisi ini berpengaruh secara psikologis pada diri anak, terutama perilaku seksual yang terimitasi dari kondisi seksual keluarga (Ibu dan Ayah) yang sering dilakukan dalam ruangan (kamar tidur) yang sama dengan anak. Penelitian ini berupaya memperjelas dampak konteks tersebut yang dilihat dari tiga hal yakni perilaku imitasi seksual, faktor yang berpengaruh dan peran guru dan orang tua dama revitaliasi diri anak secara seksual.
\end{abstract}

Kata Kunci: anak, keluarga transmigran, seksual

\section{PENDAHULUAN}

Transmigrasi sebagai upaya percepatan pembangunan daerah berkembang sering menimbulkan sejumlah masalah. Di daerah yang baru, para keluarga tidak mudah memulai pemenuhan pangan epektif karena kondisi lahan yang belum siap. Keterisolasian ruang juga 
membuat akses ke pusat-pusat perdagangan dan industri menjadi terbatas dan berdampak pada pemenuhan sandang dan papan. Banyak keluarga yang kekurangan bahan untuk mendirikan rumah "layak" tinggal yang menyebabkan mereka (para keluarga transmigran) hanya tinggal di rumah kebun (gubuk) beruang tunggal.

Di daerah Luwu Timur, sejak disematkan sebagai "daerah tujuan transmigrasi" pada tahun 1997 (Kompas, 2019), umumnya masyarakat berpendidikan dan berperokonomian rendah banyak berdatangan. Sampai saat ini, masih banyak keluarga (Ayah-Ibu-Anak bahkan ayah dan ibu mertua) tinggal dan beraktifitas (makan, tidur, bersantai dan kegiatan keluarga lainya) dalam satu ruangan. Skematik interaksi dan aktivitas ini berdampak pada psikologis anak. Dua lembaga TK melaporkan kepada peneliti (wawancara, 2019) bahwa anak didik mereka menunjukkan ekspresi seksual yang tidak wajar. VA dan NE menindih temannya (seperti pose seksual). Anak tersebut juga sering membisikkan ke telinga temannya "desahan" seksual.

Hal ini karena pada rentang usia dini (2-5 tahun) anak berada pada masa emas (golden age) yang ditandai dengan kritisnya anak dalam menirukan apa yang tampak pada lingkungannya termasuk aktivitas seksual. Sebagaimana Sigmund Freud (2001) menjelaskan bahwa anak dari aspek seksual berada pada tahapan phallice dimana pada tahap ini perkembangan seksual anak terpusat pada alat kelaminnya.

Hurlock (1996) juga mengatakan bahwa pada tahap phallice anak memiliki rasa ingin tahu yang sangat besar yang berkaitan dengan sikap dan perilaku seksualnya. Hal ini seperti saling memperlihatkan alat kelamin dengan teman sebayanya dan selalu inten atau perhatian dengan halhal yang berhubungan dengan hal tersebut. Dalam keperluan mengetahui sejauhmana kaitan antara patologi seksual keluarga migran dalam konteks tata ruang tempat tinggal dan kaitannya dengan aspek transisional daerah baru (transmigran) terhadap pertumbuhan dan perkembangan anak maka perlu ditinjau lebih jauh melalui sebuah kajian penelitian bagaimana bentuk perilaku imitasi seksual anak di tengah-tengah keluarga imigran? Seperti apa penyebab perilaku imitasi seksual yang terjadi pada anak? dan seperti apa gambaran orang tua dan guru mengatasi imitasi seksual tersebut?

\section{METODE}

Penelitian ini menggunakan Pendekatan Patologi Sosial berbentuk Studi Kasus. Pendekatan ini digunakan untuk menyelediki perilaku imitasi seksual yang ditunjukkan oleh anak usia dini dalam konteks lingkungan keluarga imigran daerah Luwu Timur Sulawesi Selatan yang hidup dalam pola rumah gubuk satu ruang dan memiliki kultur sosial, ekonomi, serta lingkungan kebudayaan baru di daerah transisional transmigrasi. Data dikumpulkan dengan melakukan wawancara terhadap anak, orang tua, guru dan elemen lainnya yang berkaitan dengan fokus penelitian. Selain itu, dilakukan juga upaya triangulasi dengan mengobservasi dan mendokumentasikan penomena yang muncul selama proses penelitian. Untuk memperoleh kesimpulan yang transferabilitif terhadap penomena, 
maka digunakan teknik analisis data dari Miles dan Huberman yang secara teknis dijalankan dengan bantuan aplikasi Nvivo.

\section{HASIL DAN PEMBAHASAN}

\section{Perilaku Imitasi Seksual Anak dalam Konteks Patologi Kehidupan Seksual Keluarga Transmigran}

Data yang terkumpul menunjukkan bahwa perilaku meniru (imitasi) seksual pada VA dan NE dipengaruhi sebagian besar oleh aktivitas seksual yang terjadi dalam keluarganya yang notabene adalah imigran. Pola rumah dengan ruang tunggal memungkinkan hubungan seksual terlihat oleh anak tanpa sengaja. Dari kondisi itu, anak mengimitasinya dan mengimplementasikannya di lingkungan dan di lembaga TK dimana ia bersekolah sehari-hari.

Dalam hal ini subjek (VA dan NE) menunjukkannya ketika mereka bermain di sekolah dengan teman-temannya. Saat bermain, baik pada teman laki-laki maupun perempuan-nya subjek melakukan gerakan menurun-naikkan tubuhnya sambil menindih ke tubuh depan dan belakang temannya.

Perilaku lainnya juga, seperti yang dituturkan pihak sekolah, subjek sering membisikkan "desahan" atau "raungan" seksual saat berinteraksi dengan temannya. Namun hal ini lebih sering dilakukan terhadap teman laki-lakinya secara "iseng" atau hanya untuk menggoda temannya ketika tidak mau diajak bermain. Tindakan memegang anggota tubuh temannya juga sering diperlihatkan. Tindakan ini juga lebih sering ke temannya yang laki-laki.

Penomena ini menurut Hurlock (1996) karena anak berada pada tahap phallice yakni adanya dorongan naluriah anak tentang hasrat bertanya dan penasaran karena rasa ingin tahu yang sangat tinggi. Oleh karena itu, rasa ingin tahu ini mendorong anak untuk mengesksplorasi lebih jauh dengan menunjukkan apa yang dirasa dan dilihat meskipun mereka tidak mengetahui esensinya baik dari aspek moralitas maupun etik perilaku sebagai manusia normal.

Oleh karena itu, show off perilaku seksual subjek seperti menindih, membisikkan dan juga memegang anggota tubuh temannya dilakukan hanya atas dasar apa yang diimitasikan secara visual dari hubungan seksual orang tuanya. Dalam hal ini, tidak ada tanda-tanda secara fisik "hasrat" seksual yang ditunjukkan oleh anak seperti merasa cemas, alat vital mengeras, tatapan tajam dan penuh hasrat atau gejala fisik lainnya ketika libido seksual memuncak.

\section{Hal-hal yang Berpengaruh terhadap Perilaku Imitasi Seksual Anak dalam Konteks Patologi Kehidupan Seksual Keluarga Transmigran}

Transisioanl daerah baru yang dihadapi para imigran di daerah luwu timur berimpikasi pada sejumlah hal. Termasuk salah satunya pola rumah tinggal yang mereka tempati. Kurangnya akses dan lemahnya ekonomi menyebabkan para keluarga hanya mampu mengupayakan rumah gubuk 
dengan pola satu ruangan. Ruangan tersebut digunakan untuk berbagai tujuan yakni digunakan sebagai ruang keluarga, kamar tidur, ruang bekerja memasak dan lainnya.

Meskipun pada dasarnya pola satu ruang adalah adalah karena alasan ekonomi, namun para keluarga imigran juga posesif terhadap anak yang artinya anak harus tidur bersama orang tua. Hal ini mengakibatkan segala aktivitas dalam ruang tersebut dialalui secara bersama-sama dengan anak. Dalam hal ini, pun ketika terjadi hubungan seksual diantara orang tua, maka baik secara sengaja maupun tidak anak sesekali menyaksikan hal tersebut. dari hal ini, anak melakukan imitasi visual sehingga meniru atau memperlihatkannya dalam situasi yang berbeda yakni di sekolah ketika bersama dengan teman-temannya.

Para orang tua tidak memiliki cukup pengetahuan untuk memahami hal ini. Pendidikan seksual bagi anak juga masih dianggap tabu. Orang tua dan guru di sekolah tidak mengetahui bagaimana melaksnakan pendidikan seksual yang tepat bagi anak. Hal ini juga dianggap tabu, famali, amoral dan melanggar nilai. Padahal ini penting untuk membelajarkan anak sejak ini bahkan dapat menjadi prisai bagi dirinya apabila ada upaya kekerasan seksual (plecehan seksual) yang terjadi pada dirinya di kemudian hari.

Selain itu, imitasi juga terjadi di sekitar lingkungan tempat tinggal anak. Meski tidak sebagai tindakan seksual yang nyata, namun aktivitas mandi bersama di kali dan areal sumur persawahan atau perkebunan secara pulgar juga memberikan dampak negatif bagi anak secara seksual. Hal ini menanamkan stigma negatif pada anak bahwa alat kelamin menjadi tidak private dan lazim untuk dipertontonkan secara pulgar kepada anak.

\section{Peran Orang Tua dan Guru dalam Mengatasi Perilaku Imitasi Seksual}

Pemahaman orang tua atau guru terhadap peran mereka dalam memberikan pendidikan seks pada anak di Luwu Timur masih tergolong rendah. Orang tua VE dan NE bahkan tidak menyadari anaknya menunjukkan perilaku seksual di sekolah. Aktivitas seksual yang mereka lakukan dirumah justru sering disaksikan oleh anaknya. Dalam hal ini, dari data yang dihimpun peneliti, tidak ada peran khusus yang dilakoni atau diupayakan orang tua dalam hal ini karena terbatasnya pemahaman dan pengetahuan orang tua tentang hal ini.

Padahal, apabila kita mempedomani Hurlock (1996), terdapat beberapa landasan bagaimana pentingya hal ini karena (1) dalam pase anak usia dini anak masih belajar bagaimana melakukan peran seks yang tepat, dan (2) anak dalam konteks sosial harus mampu menerima kenyataan bahwa mereka harus melakukan stereotip peran seks diterima secara sosial.

Tidak sama dengan orang tua, guru di sekolah sedikit lebih mengetahui tupoksi mereka sebagai pendidik dalam memberikan edukasi seks yang tepat bagi anak. Namun demikian, guru masih sebatas memberikan upaya insidental bukan tindakan preventif yang terencana dan terintegrasi dalam tema-tema pembelajaran. 
Peran guru dalam upaya memberikan pendidikan seksual kepada anak seharusnya memperhatikan pendapat dari ahli Ratih Zulhaqi (2013) yang megnemukakan bahwa orang tua dan guru harus berperan bahkan sejak anak umur 2 tahun dimana anak sudah bisa di pisahkan tidurnya dari orang tua. Selain melatih kemandirian tidur terpisah juga dilakukan untuk menghindari anak melihat sesuatu yang belum sepantasnya mereka lihat dan dengar, yakni ketika kedua orang tua sedang melakukan hubungan seksual. Bila otak belum siap menerima paparan seks, maka bisa jadi otak akan ketagihan.

Selanjutnya, guru di sekolah dapat berperan sebagaimana arahan dari Moeslichatoen (1999) bahwa pembelajaran yang di lakukan di Taman kanak-kanak menggunakan pendekatan tematik, di mana tidak ada mata pelajaran didalamnya. Pembelajaran di PAUD juga di berikan secara terpadu (integratefcoricculim) dimna satu tema terdiri atas beragam kegiatan di dalamnya, dan satu kegiatan memiliki tujuan untuk mengembangkan satu aspek perkembangan yang di miliki anak secara terpadu.

Penerapan pendidikan seks bagi anak usia dini harus sesuai dengan kebutuhan anak, di mana anak pada usia tersebut tengah berkembang rasa ingin tahu dan dorongan eksplorasi yang sangat tinggi terhadap dirinya sendiri, teman sebayanya, perbedan fisik dan alat kelamin yang mereka miliki. guru dapat masuk dalam proses perkembangan peran seks ini, sehingga anak dapat pendampingan yang tepat dan terarah.

Perencanaan pendidikan seks bagi anak usia dini harus di buat secara integrasi dengan mengunakan pendekatan terpadu yang di organisasi melalui tema-tema pembelajaran yang terdapat kurikulum PAUD yang bersangkutan. Pokok materi dalam pendidikan seks bagi anak usia dini dirumuskan dalam perogram semester (PROSEM) rencana perogram pembelajaran mingguan (RPPM), rencana perogram pembelajaran harian (RPPH).

Materi pendidikan seks bagi anak usia dini dapat melebur kedalam lima ruang lingkup kurikulum yang meliputi bidang perkembangan moral dan nilai-nilai agama, bidang pengembangan sosial emosional, bidang pengembangan bahasa, bidang pengembangan kongnitif, bidang pengembangan fisik motorik.

\section{KESIMPULAN DAN SARAN}

Transisional wilayah baru berpengaruh secara psikologis pada diri anak, terutama perilaku seksual yang terimitasi dari kondisi seksual keluarga (Ibu dan Ayah) yang sering dilakukan dalam ruangan (kamar tidur) yang sama dengan anak. Orang tua tidak menyadari dampak tersebut, sehingga mereka kurang maksimal dalam merevitalisi peran mereka pada diri anak. Dalam hal ini, guru sebagai unsur terdidik yang memberikan pendidikan seksual di sekolah belum mampu mengintegrasikan pendidikan seks yang sesuai dengan tumbuh kembang anak dalam pembelajaran. 


\section{DAFTAR PUSTAKA}

Crain, W. (2001). Teori Perkembangan: Konsep dan Aplikasi (Terjemahan Yudi Santoso). Yogyakarta: Pustaka Pelajar

Hurlock, Elizabeth B. (1996). Psikologi Perkembangan; Suatu Pendekatan Sepanjang Rentang Kehidupan. Edisi Kelima. Jakarta: Erlangga

Sardiman AM, (2001), Interaksi dan Motivasi Belajar Mengajar, Jakarta: Raja Grafindo Persada Moeslichatoen, (1999), Metode Pengajaran di Taman Kanak-Kanak. Jakarta: PT. Rineka Cipta.

Ratih, Zulhaqi. Perkembangan Seksual Anak, dalam https://health.detik.com/, diunduh pada Juli 2020 